\title{
看護研究報告：
}

\section{鹿児島県における \\ 専門看護師・認定看護師に関する教育ニーズ調査}

\author{
山口さ抢り*,八代利 香*, 吉留厚子*
}

日本看護協会による資格認定制度が創設され10年余り経過したが，鹿児島県にはいずれ の養成機関も存在しない。鹿児島県内に就業する看護師を対象に, 専門看護師ならびに認 定看護師に関する教育ニーズを明らかにし，キャリア形成を支援するための教育を検討す ることを目的として調査を行なった。調査期間は平成 20 年 9 月で, 鹿児島県内 40 病院の看 護師1, 800名を対象とした。調査用紙を配布した看護師 1,800 名のうち 1,258 名より回答が 得られ（回収率69.9\%), 有効回答は999名（有効回答率79.4\%）であった。その結果, 40.9\%が専門看護師資格を, また $56.5 \%$ が認定看護師資格の取得を希望していた。資格取 得を希望する分野のうち, 最も多い専門看護師資格は「がん看護」, ついで「急性・重症 患者看護」, 認定看護師資格は「救急看護」ついで「緩和ケア」であった。鹿児島県にお いては, 資格認定のための教育機関が存在しないという現状と, 離島・へき地を有すると いう地理的条件が, 看護師の教育ニーズを阻む大きな要因となっていた。看護師のキャリ ア形成を支援するために，キャリアデザインに関する個別的な相談体制および柔軟な教育 カリキュラムの構築の必要性が示唆された。

\section{(1)専門看護師 (2)認定看護師 (3)教育ニーズ (4)キャリア形成 （5)離島・へき地}

\section{は じめに}

高度化・専門分化が進む近年の医療現場にお いて, 看護ケアの広がりと看護の質向上を目的 として日本看護協会による資格認定制度が創設 され10年余り経過した。看護系大学院の増加に 伴い, 専門看護師 (Certified Nurse Specialist, CNS）の教育を行なっている看護系大学院修 士課程は, 平成 17 年 3 月現在の 17 大学院 60 課程 から平成 21 年 8 月現在では 43 大学院 119 課程と なり, その増加は顕著である。また, 認定看護 師 (Certified Nurse, CN) の教育を行なう日 本看護協会が認定した教育機関は，平成17年 12 月現在の 17 機関 35 課程から平成 21 年開講の課程

\footnotetext{
* = 890-8544 鹿览島市桜ヶ 丘8-35-1 鹿児島大学医学部保健学科看護学専攻 (受付：2009年 9 月 30 日)
}

を含めると68課程となり，ほぼ倍増している。 平成 21 年 8 月 1 日現在, 専門看護師 302 名, 認 定看護師 5,794 名が登録されており，この資格 認定制度によって多様なヘルスケアニーズに応 えた水準の高い看護実践・看護ケアが提供され ることはもとより, 看護師のキャリア形成にお いても魅力ある選択肢となっている。

しかしながら，地区別の登録者数をみると， 九州地区では専門看護師12名（総数の $3.97 \%$ ), 認定看護師 543 名（総数の9.37\%）と少なく, 鹿児島県に至っては, 専門看護師 0 名, 認定看 護師60名という現状であり, 地域によって偏在 していることがわかる。その一因として，地域 による教育機関数の格差による影響が考えられ る。殊に九州においては, 専門看護師の教育を 行なう看護系大学院修士課程 4 校, 認定看護師 の教育機関は 6 課程のみであり，鹿児島県にお 
いてはいずれの教育機関も存在しない。

鹿児島県は, 離島・へき地を抱えており, 健 康格差の縮小を図りながら, 住民が県内どこに 住んでいても, その医療ニーズに応じて, 安全 で質の高い医療サービスを受けられる地域社会 の形成を目指している ${ }^{1)}$ 。医師の地域偏在や不 足という現状もある中で, 住民の複雑・多様化 した健康ニーズに応えていくためには, 看護師 の臨床実践能力に期待される部分も大きく, 社 会的ニーズに呼応した形での看護師のキャリア 形成が切望される。

そこで, 鹿児島県内に就業する看護師を対象 に，専門看護師ならびに認定看護師に関する教 育ニーズを明らかにし，キャリア形成を支援す るための教育を検討することを目的として調査 を行なったので報告する。

\section{研 究 方 法}

\section{1. 研究対象}

事前に調査協力を依頼し, 看護部門の代表者 から承諾を得た鹿児島県内 40 病院の看護師 1,800名である。サンプルサイズを考慮し, 各 病院に勤務する看護者の約 $30 \%$ が対象となるよ う依頼数を設定の上, 実際の対象者は, 看護部 門の代表者にランダムに選定してもらった。

\section{2. 調查方法}

調査期間は，平成 20 年 9 月 1 日から平成 20 年 9 月30日の 1 か月間であり, 留め置き法にて実 施した。調査用紙は各病院に手渡し及び郵送に より配布の後，個別に郵送で回収した。

\section{3. 調査内容}

調査用紙の質問項目は，専門看護師制度およ び認定看護師制度それぞれに関して設定し, 制 度の認知, 資格の取得希望の有無, 資格の取得 を希望する場合はその理由と取得したい分野, 養成コースを受講できる可能性と受講を可能に する環境条件, 県内に養成コースが開設された 場合の受講希望, 資格の取得を希望しない場合 はその理由および対象者の背景を知る項目で構 成した。

\section{4. 倫理的配慮}

個別の調查用紙にて, 調查の趣旨・目的と方 法, 調査対象の個人情報の保護およびデー夕の 匿名化, デー夕の管理方法, 調査参加の自由お よび参加拒否によって不利益を被らないことの 保障, 結果の公表について説明し, 同意が得ら れた場合のみ研究への参加協力を求めた。ま た, 研究への参加同意が得られた場合の調査用 紙の回収は, 対象者毎個別に郵便で返送しても らうこととし, 調査対象の意思を尊重できるよ う配慮した。

\section{5. 分析方法}

統計ソフト SPSS Statistics 17.0を用いて, すべてのデータについて記述統計を行なった。 さらに, 資格の取得希望の有無と対象者の背景 との関係について $\chi^{2}$ 検定を行なった。

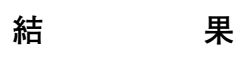

\section{1. 対象者の背景}

調查用紙を配布した看護師1,800名のうち 1,258名より回答が得られ (回収率69.9\%), 有 効回答は999名 (有効回答率79.4\%) であった。 対象者の背景は, 表 1 に示した。

対象者の年齢は，30歳代が382名 $(38.2 \%)$ と最も多く，続いて20歳代297名 (29.7\%)，40 歳代 253 名 $(25.3 \%), 50$ 歳以上 67 名 $(6.7 \%)$ であった。

看護師経験年数は10～19年が363名 $(36.3 \%)$ と最も多く，続いて $5 \sim 9$ 年 $(27.2 \%), 20$ 年 以上 215 人 $(21.5 \%), 1 \sim 4$ 年 149 人 $(14.9 \%)$ であった。

\section{2. 資格認定制度の認知状況}

資格認定制度の認知状況は, 専門看護師制度 を「知っている」が534名 (53.5\%)，「聞いたこ とがあるがよくわからない」が387名(38.7\%), 「知らない」が78名 (7.8\%) であった。一方, 認 定看護師制度を「知っている」が808名 (80.9\%), 「聞いたことがあるがよくわからない」が184 名 $(18.4 \%)$ ，「知らない」が 7 名 $(0.7 \%)$ で あった。 
表 1. 対象者の背景

\begin{tabular}{llrr} 
& & & $\mathrm{n}=999$ \\
\hline 項目 & \multicolumn{1}{c}{ 区分 } & 人数 & \multicolumn{1}{c}{$\%$} \\
\hline 年齢 & 20歳代 & 297 & 29.7 \\
& 30 歳代 & 382 & 38.2 \\
& 40 歳代 & 253 & 25.3 \\
& 50 歳以上 & 67 & 6.7 \\
\hline 看護師経験年数 & $1 \sim 4$ 年 & 149 & 14.9 \\
& $5 \sim 9$ 年 & 272 & 27.2 \\
& $10 \sim 19$ 年 & 363 & 36.3 \\
& 20年以上 & 215 & 21.5 \\
\hline 役職 & 師長クラス & 88 & 8.8 \\
& 副師長 (主任) クラス & 150 & 15.0 \\
& スタッフナース & 741 & 74.2 \\
& その他 & 20 & 2.0 \\
\hline
\end{tabular}

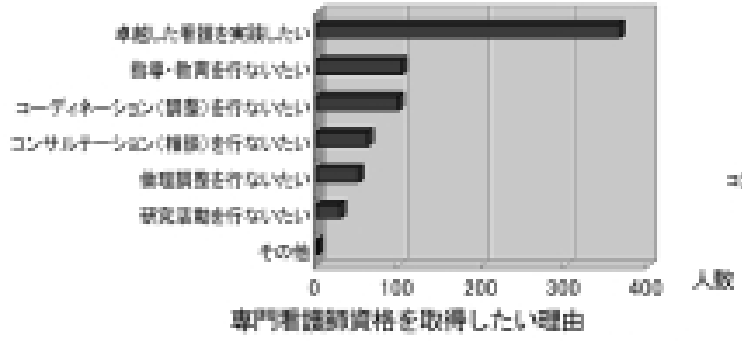

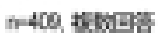

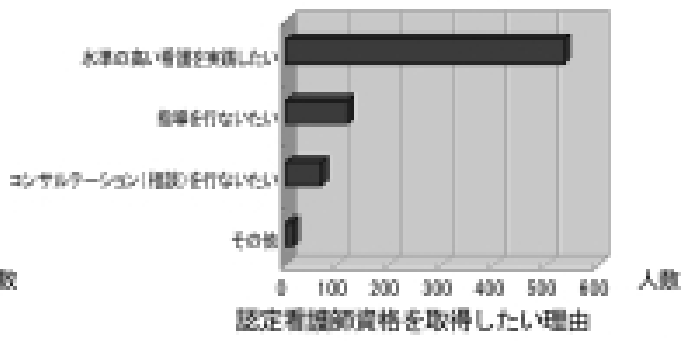

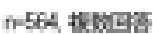

図 1. 資格取得を希望する理由

\section{3. 資格取得の希望とその理由}

専門看護師資格の取得希望は，「取得したい と思う」409名 (40.9\%)，「取得したいと思わ ない」590名（59.1\%）であった。「取得したい と思う」と回答した409名にその理由を質問し たところ，「熟練した看護技術と知識を用い て, 卓越した看護を実践したい」が365名と最 も多く，次いで「看護実践を通して他の看護職 者に指導・教育を行ないたい」が104名,「必要 なケアが行なわれるために，保健医療福祉に携 わる人々の間のコーディネーション（調整）を 行ないたい」が99名,「看護職者に対し, コン サルテーション（相談）を行ないたい」が63 名,「倫理的な問題や葛藤の解決を図る倫理調 整を行ないたい」が51名,「実践の場で研究活 動を行ないたい」が29名,「その他」が 2 名で
あった（図 1 )。また，「取得したいと思わな い」590名にその理由を質問したところ，「自分 自身のキャリアが不足している」が272名と最 も多く，次いで「教育研修期間が遠い」が218 名,「経済的に取得が難しい」が151名であっ た。

一方, 認定看護師資格の取得希望は, 「取得 したいと思う」564名（56.5\%）「取得したい と思わない」435名 (43.5\%) であった。「取得 したいと思う」と回答した 564 名にその理由を 複数回答可として選択してもらったところ,

「熟練した看護技術と知識を用いて，水準の高 い看護を実践したい」が534名と最も多く, 次 いで「看護実践を通して他の看護職者に指導を 行ないたい」が119名,「看護職者に対し, コン サルテーション (相談) を行ないたい」が69 
名，「その他」が15名であった（図 1 )。また，

「取得したいと思わない」435名にその理由を 質問したところ，「教育研修期間が遠い」が216 名と最も多く, 次いで「自分自身のキャリアが 不足している」が206名,「経済的に取得が難し い」が144名であった。

\section{4. 資格取得を希望する分野}

資格取得を希望する分野について, 専門看護 師・認定看護師それぞれ 1 位〜 3 位で回答して もらい，各順位の度数を積み上げ式にグラフ化 した(図 2 , 図 3 参照)。

専門看護師資格を「取得したいと思う」と回 答した409名が希望する分野のうち， 1 位〜 3 位の合計が最も多かったのは「がん看護」の191

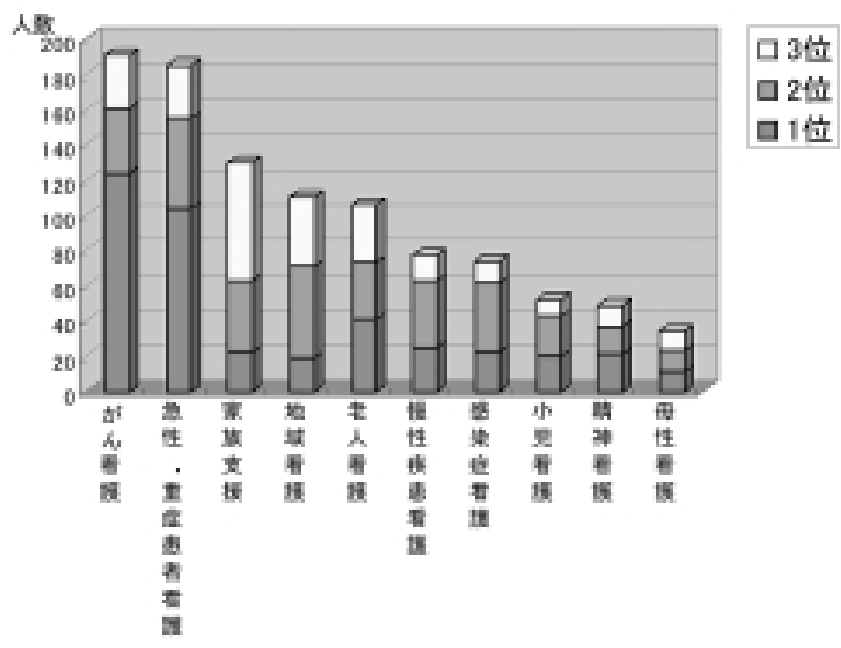

図 2. 取得したいと思う専門看護師資格の分野

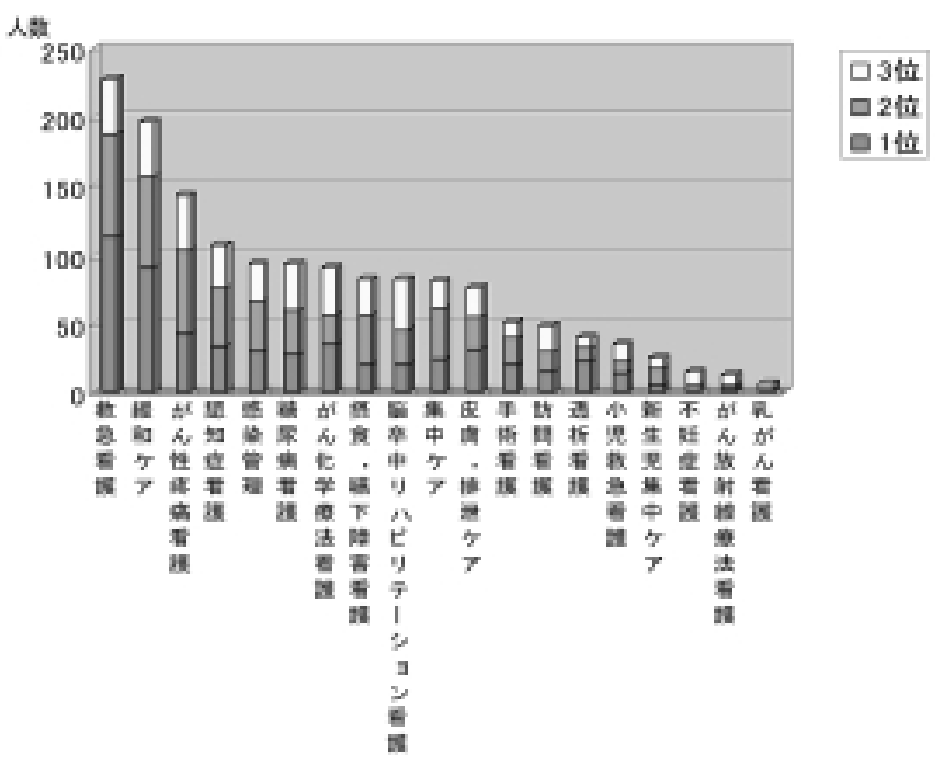

図 3. 取得したいと思う認定看護師資格の分野 
名であった。次いで「急性・重症患者看護」が 185 名と多く, 以下「家族支援」,「地域看護」,

「老人看護」の順であった。

認定看護師資格を「取得したいと思う」と回 答した 564 名が希望する分野のうち，1 位〜 3 位の合計が最も多かったのは「救急看護」の228 名であった。次いで「緩和ケア」が197名と多 く, 以下「がん性疼痛看護」,「認知症看護」, 「感染管理」「糖尿病看護」の順であった。

\section{5. 養成コースを受講できる可能性と受講を可 能にする環境条件}

調査時点での資格認定のための養成コース受 講の可能性, および現状での受講が困難である 場合, どのような環境条件が整えば受講可能か について質問した。併せて, 鹿児島県内に養成 コースが開設された場合の受講希望についても 質問した。

専門看護師資格を「取得したいと思う」と回 答した409名が専門看護師養成コースを受講で きる可能性は，「環境が整えば可能である」が 240 名 $(58.7 \%)$ と最も多く, 以下「可能性は 極めて低い」155名 (37.9\%), 「現状で可能で ある」14名 $(3.4 \%)$ であった。「環境が整えば 可能である」「可能性は極めて低い」と回答し た395名に，どのような環境条件が整えば受講 可能かについて質問したところ，「研修機関が 近くにあれば」が 305 名と最も多く, 続いて「職 場での支援があれば」が235名, 以下「研修期 間が短縮されれば」208名，「諸経費が軽減され れば」206名,「自分自身のキャリアが充足され れば」116名,「その他」25名であった（図 4 ）。
鹿児島県内に養成コースが開設された場合の受 講希望は，「環境が整えば受講したい」が189名 (46.2\%) と最も多く，以下「検討したい」 129 名 $(31.5 \%)$ ，「是非したい」90名 $(22 \%)$,「し たくない」 1 名 $(0.2 \%)$ であった。

認定看護師資格を「取得したいと思う」と回 答した564名が認定看護師養成コースを受講で きる可能性は，「環境が整えば可能である」が 331 名 $(58.7 \%)$ と最も多く，以下「可能性は 極めて低い」201名 $(35.6 \%)$,「現状で可能で ある」32名（5.7\%）であった。「環境が整えば 可能である」「可能性は極めて低い」と回答し た532名に，どのような環境条件が整えば受講 可能かについて質問したところ，「研修機関が 近くにあれば」が412名と最も多く，続いて「職 場での支援があれば」が309名, 以下「諸経費 が軽減されれば」288名，「研修期間が短縮され れば」223名，「自分自身のキャリアが充足され れば」136名，「その他」54名であった（図 4）。 鹿児島県内に養成コースが開設された場合の受 講希望は，「環境が整えば受講したい」が273名

(48.4\%) と最も多く，以下「是非したい」が 166名 $(29.4 \%)$ 「検討したい」125名 $(22.2 \%)$ が「したくない」との回答は皆無であった。

\section{6. 対象者の背景と資格取得意思との関係}

対象者の背景と専門看護師資格・認定看護師 資格それぞれの取得希望との関係については, 関連性に関する統計学的な有意差は認められな かった。

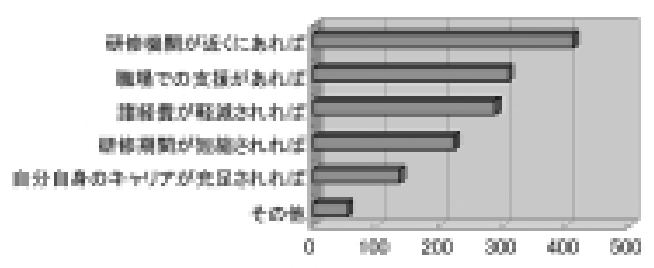

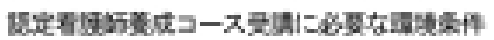
$n=582$, watod

図 4.養成コース受講に必要な環境条件 


\section{考}

察

\section{1．資格認定制度に関する教育ニーズ}

資格認定制度が創設され 10 年余り経過した が，専門看護師制度を「知っている」と回答し たものは約半数であり，制度に関する認知が十 分とは言い難い状況であった。一方, 認定看護 師制度を「知っている」と回答したものは約 8 割を占めており, 認定看護師制度は広く認知さ れてきたと言える。鹿児島県においても, 認定 看護師の登録者数が増加してきており, それに 伴い自らの病院または研修等で認定看護師の活 動を身近で目にする機会が増えてきたことがそ の要因として考えられる。

このような背景の中, 資格取得希望者は, 専 門看護師 409 名 $(40.9 \%)$, 認定看護師590名 (56.5\%) であり，いずれも約 9 割が「卓越し た看護を実践したい」「水準の高い看護を実践 したい」という理由を挙げていた。これらの結 果は，年齢による優位な差は認められず，より 看護者として優れた実践を求める者にとって, 資格認定制度は魅力ある選択肢になってきてい ると考えられる。特に, 認定看護師は, 身近な モデルの存在により, 具体的なキャリアイメー ジを描き易くなり取得希望のニーズに結びつい ていることが推察された。

次に, 資格取得を希望する分野についてみて みると, 専門看護師では「がん看護」, 認定看 護師では「救急看護」が最も多く，九州ブロッ クの看護師を対象とした調査結果 ${ }^{2)}$ と一致して いた。現在の医療現場において, 看護師は, あ らゆる年代層のがん患者に場を問わず看護を提 供することを求められている。それゆえ, 看護 師の直面する問題も複雑多岐にわたっており, 看護師は臨床現場において「がん看護」に関す る専門的知識の必要性を実感し,「がん看護」 専門看護師教育へのニーズにつながったと考え られる。また，昨今の医師不足や地域偏在を鑑 みると, 救急看護医療の現場における看護師の 果たす役割は増大してきている。平成19年12月 の厚生労働省医政局長通知では, 看護師の業務 拡大の 1 つとして「救急医療等における診療の
優先順位の決定」が提示され, 看護師の能力の 研鑽が求められている。特に鹿児島県は, 有人 離島28島のうち15島が無医島となっているなど 医師の地域偏在や離島・へき地での医師不足が みられ ${ }^{1)}$, 看護師が救急に関する専門的な知 識・技術を求められる場面が多いことが推察さ れ,「救急看護」認定看護師への教育ニーズに つながったと考えられる。

\section{2. 養成コースの受講を可能にする条件とキャ リア形成を支援する教育体制}

資格取得を希望しない者の理由をみると, 専 門看護師・認定看護師ともに「自分自身のキャ リアが不足している」「教育研修機関が遠い」 「経済的に取得が難しい」が上位を占めてい た。また，資格取得を希望する者であっても， 調查時点での資格認定のための養成コース受講 の可能性について「現状で可能である」と回答 した者は専門看護師で14名 (3.4\%)，認定看護 師は 32 名 $(5.7 \%)$ といずれも少なく，どのよ うな環境条件が整えば受講可能かという問いに は，専門看護師・認定看護師のいずれも，「研 修機関が近くにあれば」「職場での支援があれ ば」という回答が上位を占めていた。この結果 から，鹿児島県における養成コースの受講を可 能にする条件について考えてみたい。

まず，人的な条件として，資格認定制度およ び看護師自身のキャリアに関する認識が挙げら れる。調查によると, 看護師は養成コースの受 講に際して，自身のキャリア不足を認識してい た。前述したとおり，認定看護師は，認定看護 師数の増加により具体的なキャリアイメージが 浸透しつつあると考えられるが，専門看護師に ついては鹿児島県の登録者が 0 名という状況か ら，その活動内容はもとより受験資格など制度 の詳細についての認知が十分でないことが影響 していると考えられる。また，専門看護師の教 育課程が大学院修士課程であることも, 看護師 が自己のキャリア不足を意識する一因として考 えられるだろう。賀沢ら ${ }^{3)}$ は, 病院看護師の調 査に怙いて, 大学院入学資格審査の認知が低い ことを指摘している。また，神田ら ${ }^{4)}$ は，専門 
看護師の教育ニーズに関する調査において, 専 門看護師を希望しない理由として大学院の受験 や教育のレベルへの適応への心配を報告してい る。すなわち, 専門看護師制度については, 制 度の概要のみならず，大学院の出願資格や具体 的なカリキュラムについての情報提供が養成 コース受講の前提条件として挙げられるだろ う。

次に, 物理的な条件として, 通学可能な教育 機関の存在が挙げられる。前述の通り, 鹿児島 県には専門看護師・認定看護師いずれの教育機 関も存在せず，九州に目を転じても専門看護師 の教育を行なう看護系大学院修士課程 4 校, 認 定看護師の教育機関 6 課程のみである。とりわ け，今回の調査でニーズが高かった「救急看 護」認定看護師の教育機関は九州内には存在せ ず，最も近い教育機関は大阪府であり，県内か らの通学は困難である。廣瀬ら ${ }^{5)}$ は, 自らの大 学への専門看護師教育課程への進学を希望する 理由として，「自宅や職場から通学が可能」と いう回答が圧倒的に多かったと報告している。 しかし，鹿児島県においては，看護師が資格認 定制度に関する教育を欲しても，地理的問題に よりアクセスすらままならない状況がある。ま た, 調査では, 鹿児島県内に養成コースが開設 された場合，「是非したい」「環境が整えば受講 したい」と回答したものが専門看護師・認定看 護師ともに 7 割を超えており，鹿児島県内また は通学可能な近県への教育機関の整備が重要な 条件として示唆された。

最後に, 社会的な条件として, 進学をサポー トする職場環境が挙げられる。進学に際して は, 在学中も含め経済的な基盤が確保されるこ とが必須である。そのためには，就業と学業の 両立, あるいは学業に専念するとしても雇用を 確保するなどの職場のサポートが求められるだ ろう。資格取得の意思は, 年齢・看護師経験年 数・役職で有意差は認められなかったが, 看護 師のライフサイクルを通じて，そのキャリア アップをサポートするような職場環境が必要な 条件となると考えられる。

以上を踏まえ，鹿児島県における看護師の
キャリア形成を支援する教育体制について考察 してみたい。

まず，資格認定制度および教育機関，ならび にキャリアデザインについての情報提供と相談 機能の整備が必要であると考える。キャリア アップを目指す看護師の教育的・社会的背景は 様々であり，また，鹿児島県という地理的条件 を踏まえて個々の条件に応じた具体的なキャリ アデザインを具現化する機会と場を整備する必 要があるだろう。加えて, 進学をサポートする 職場環境の実現へ向けて, 職場の管理者への対 応も重要となると考える。今回，管理者への調 査は実施していないが，松下らの看護職代表者 への調査 ${ }^{6}$ では, 大半が自施設に専門看護師を 必要と考えているものの, その具体的導入につ いて検討している割合は少ないと報告されてい る。したがって，管理者への大学院の出願資格 等に関する情報提供と, 組織における専門看護 師あるいは認定看護師育成の具体的な教育計画 や体制についての相談機能も整えていく必要が あるだろう。

また，鹿児島県において，看護師の資格認定 制度に関する教育ニーズに応えていくために は, 県内から通学可能な教育機関を整備するこ とが重要かつ急務であるということが本調查結 果から示唆された。しかし, 離島やへき地を有 する地理的状況を考えると, 教育の提供方法や 学習形態についても検討する必要がある。具体 的には, e-learning やサテライトキャンパスに よる講義，また夜間や休日の開講および長期履 修制度など，看護師としての実践を深めなが ら，キャリアアップに向けての学習が可能にな るような, 柔軟なカリキュラムの構築が重要で あると考える。

\section{結}

\section{論}

鹿児島県内に就業する看護師を対象に，専門 看護師ならびに認定看護師に関する教育ニーズ を調査した結果, 約半数のものが資格取得を希 望していながらも，様々な条件によって進学に 至っていないことが明らかとなった。特に，い ずれの教育機関も存在しないという現状と，離 
島・へき地を有するという地理的条件が, 看護 師の教育ニーズを阻む大きな要因となってい た。看護師のキャリア形成を支援するために， キャリアデザインに関する個別的な相談体制お よび柔軟な教育カリキュラムの構築の必要性が 示唆された。

\section{謝辞}

調査にあたりご協力いただきました皆様に, 深く感 謝申し上げます。

\section{文献}

1 ）鹿児島県保健医療計画 $2008 ； 221-355$.

2 ) 山本捷子, 本田多美枝, 寺門とも子. 九州ブロッ ク $\mathrm{N}$ 系列病院における看護職者のキャリア形成に 関する学習ニーズ調查. 日本赤十字九州国際看護 大学 Intramural Research Report 2005 (3) : 208
$-218$.

3 ) 賀沢弥貴, 山田聡子, 飯島佐知子, 他. 愛知県立 看護大学の教育改革に関する調査(4)一病院で働く 看護師の本学大学院への進学ニーズ一. 愛知県立 看護大学紀要 $2005 ; 11 ： 95-107$.

4) 神田清子, 牛久保美津子, 齋藤泰子, 他. 群馬県 に㧍ける専門看護師教育ニーズに関する調查. 群 馬保健学紀要 $2005 ; 26: 89-95$.

5 ）廣瀬幸美, 松下由美子, 石田貞代, 他. 山梨県内 看護職者の大学院（専門看護師教育課程）への進 学に関するニーズ実態調查（その 1$)$ 一看護職者 への調查一. 山梨県立大学看護学部紀要 2008 ; $10: 83-92$.

6 ）松下由美子, 廣瀬幸美, 松下裕子, 他. 山梨県内 看護職者の大学院 (専門看護師教育課程) への進 学に関するニーズ実態調査（その 2 ) 一看護職代 表者への調査一. 山梨県立大学看護学部紀要 $2008 ; 10$ : 103-109. 


\title{
A Survey of Educational Needs for Certified Nurse Specialists and Certified Nurses in Kagoshima Prefecture
}

\author{
Saori YAMAGUCHI*, Rika YATSUSHIRO* and Atsuko YOSHIDOME*
}

\begin{abstract}
Although the nurse certification system was established by the Japanese Nursing Association in 1994, there are currently no educational institutions in Kagoshima Prefecture for certified nurse specialists (CNS) and certified nurses (CN). The aim of this study was to sound out generalist nurses working in hospitals in Kagoshima Prefecture on CNS and CN educational needs in order to determine methods of supporting those aspirational nurses in the development of their careers. A (self-administered) questionnaire survey was conducted on 1,800 nurses working at 40 hospitals in Kagoshima Prefecture in September 2008. Responses came from 1,258 (69.9\%) nurses, of which 999 (79.4\%) were valid. Of the respondents, $40.9 \%$ indicated they would like to obtain a CNS license, while 56.5\% indicated they would like to obtain a CN license. Regarding the CNS license, most respondents wanted to obtain CNS qualification in cancer nursing, followed by acute/critical care nursing. Regarding the CN license, CN qualification in emergency nursing came to the top followed by palliative care nursing. As Kagoshima Prefecture is comprised of remote islands and remote rural areas, it is a disadvatage for many nurses geographically to staisfy their education needs. These results suggest that in order to support nurses' career development, it is necessary to establish an individual consultation system for career development and develop a flexible educational curriculum.
\end{abstract}

${ }^{*}$ School of Health Sciences, Faculty of Medicine, Kagoshima University, Kagoshima, Japan 